Research Article

\title{
Effectiveness of Agricultural Extension Services in Reducing Poverty of Apple Growers of District Bagh, Azad Jammu and Kashmir
}

\author{
Sana Javeid* and Khalid Nawab
}

Department of Agricultural Extension Education and Communication, The Agricultural University, Peshawar, KP-Pakistan.

Abstract | The current research study was conducted to determine poverty levels of apple orchard growers and association of different extension services with poverty in district Bagh, Azad Jammu and Kashmir (AJ\&K). Primary data from 306 respondents were collected using multistage simple random sampling techniques. The data were collected using an interview schedule; analysis were carried out by using cross-tabulation, frequency counts, percentages through Statistical Package for Social Sciences (SPSS). To measure the poverty level of apple orchard growers, poverty score card was employed. In addition, bivariate analysis was used to examine relationship between various extension practices and poverty. Results of the study revealed that majority (60.1\%) of the respondents were non-poor, out of which $90.8 \%$ received extension services. Furthermore, out of the non-poor category, $58.7 \%$ were visited by the extension agents occasionally. However, $27.2 \%$ were contacted by holding group meetings and $25 \%$ through home/farm visits. Likewise, $49.5 \%$ from non-poor category were empowered in the course of community empowerment and $66.8 \%$ attended trainings arranged by extension agents. In addition, out of all poor categories least number of growers (4.9\%) were found extremely poor and $10.5 \%$ in the transitory non-poor category. The association of extension services, visits paid by the extension agents, extension contact methods, strategies and trainings showed significant relationship with poverty. Hence, it is recommended that efforts are needed to regularize all extension activities for poverty reduction in the study area.

Received | March 17, 2021; Accepted | July 24, 2021; Published | September 14, 2021

*Correspondence | Sana Javeid, Department of Agricultural Extension Education and Communication, The Agricultural University, Peshawar, KP-Pakistan; Email: sanajaveid123@gmail.com

Citation | Javeid, S. and K. Nawab. 2021. Effectiveness of agricultural extension services in reducing poverty of apple growers of District Bagh, Azad Jammu and Kashmir. Sarbad Journal of Agriculture, 37(4): 1342-1354.

DOI | https://dx.doi.org/10.17582/journal.sja/2021/37.4.1342.1354

Keywords | Apple, Chi-square, Extension services and visits, Poverty levels, Poverty scorecard

\section{Introduction}

A griculture is an important pathway for the rural poor to move out of poverty (WB, 2008). Commitment to rural development has been reaffirmed with the adoption of sustainable development goal 1 and 2, which aim to end poverty and hunger by 2030 respectively (UN, 2015).

Agricultural growth can stimulate economic growth and reduce poverty in developing countries. Globally, poverty has been dropped during the last thirty years, and credit for this achievement goes to agriculture growth (WB, 2008; Dewbre et al., 2011). Similarly, Bigsten et al. (2003); Amalu, (2005) explained that, to reduce poverty or increase household income, it is fundamental that economic policies must be strategies oriented to promote rapid rural economic growth. Hence, for expanding the growing capacity of the agriculture sector, agriculture extension is a significant 
development intervention for the promotion of propoor agricultural and economic development in an intensive way (WB, 2007). However, agriculture and agricultural extension services are confronting various issues in present times and finding worthy solutions is not easy. Agricultural extension services must provide strong connections between producers, agricultural research and other sources of information. Therefore, the dire need of the country's agricultural development; intensifying the level of extension operations and establishing a relevant extension services based on modern methods (Zivkovic et al., 2009).

Understanding the relationship between agricultural technology adoption, productivity, and poverty reduction has been the keen interest for long time (Minten and Barret, 2006). Nevertheless, in recent years many developing countries have reaffirmed the essential role that agriculture extension can play in agricultural development (Birner and Anderson, 2007). This renewed interest in agriculture extension is linked to the discovery of the role that agriculture extension needs to play in reducing persistent poverty (World Bank, 2007b; Birner and Anderson, 2007). Poverty is still prevailing in developing countries despite so many efforts have been made to reduce it over the past half century. This has been largely due to lack of consideration of local poverty issues, inappropriate implementation and management procedures. Thus, poverty reduction refers to the implementation of appropriate strategies for suitable use of scarce resources by the maximum impact on poor through allocation of resources to activities that have the potential to contribute in reducing deprivation and vulnerability in poor communities (Asante and Ayee, 2004). Agricultural extension services could not commendably achieve the goals without addressing the most vulnerable farmers in developing countries (Sachs, 2006; World Bank, 2008).

Dercon (2008) stated that the lower rates of poverty were contributed by investing in infrastructure and also in agricultural extension services. The findings regarding agriculture extension showed that at least one extension visit reduces headcount poverty by $9.8 \%$ and increases consumption growth by $7.1 \%$. Approximately $75 \%$ of global poor people live in rural localities and generally make their living necessities from the land where they live. In Pakistan, the $6^{\text {th }}$ most populous country of the world, more than $60 \%$ of the population is also living in rural areas and asso- ciated with farming for their livelihoods. Out of this massive rural people, majority are facing the problem of poverty (IFAD, 2016).

The State of AJ\&K comprises an area of 13,297 sq. $\mathrm{km}$. The projected population of AJ\&K in 2018 was 4.112 million and lies between longitude $73^{\circ}-75^{\circ}$ and latitude $33^{\circ}-36^{\circ}$ and falls within the Himalayan belt. Presently, AJ\&K is divided into three divisions $(\mathrm{Mu}-$ zaffarabad, Poonch and Mirpur), with 10 administrative districts.

Under the fluctuating agricultural situation, it has been understood that the horticulture sector plays a vigorous role in providing livelihood safety to the farmers globally. Half of the world's deciduous fruit tree production is represented by apple (FAO, 2000). Apple farming serves as a primary source of income in northern areas of Pakistan (Ritter, 2006). In temperate hilly territories of Ziarat, Quetta, Mastung, Murree hills, Qalat, Pishin, Swat, Chitral, Manshera, Kalam, Gilgit, Skardu, Chilas, Hunza and Azad Kashmir apple is successfully cultivated in Pakistan. In districts of Bagh, Poonch,Sudhnoti, Muzaffarabad and Neelum, apple is a major fruit crop in Azad Jammu and Kashmir (AJ\&K). Red Chief, Kashmiri Amri, Sky Spur, Golden Delicious, Red Delicious, Starking, Fuji, Star Crimson, Red Labnani and Royal Gala are among the commercial varieties of apple grown in Pakistan and AJ\&K (Ahmed and Raza, 2005). The per hectare yield of apple in Pakistan is very low because end users don't adopt recommendations, especially plant protection measures (Siddiqui et al., 2006).

$\mathrm{AJ} \& \mathrm{~K}$ has a diverse climate, ranging from sub-humid subtropical to temperate, depending upon altitude and rainfall. As the $\mathrm{AJ} \& \mathrm{~K}$ has a wide range of suitable agro-climatic conditions for fruit production and among all fruits, apple is prominent temperate fruit but income returns vary from farmer to farmer depending on various factors. Agriculture in Azad Jammu \& Kashmir is operating on a subsistence level. Although the average size of the small farms is 0.6 hectares, however, size of small farms probably 0.2 to 0.3 hectares or even less. Hence, orchard farming is associated with many constraints resulting in low productivity. Although much literature is found on the association of poverty with different extension services, yet it is unidentified which extension service is strongly associated with poverty reduction. The government of Azad Jammu \& Kashmir has es- 
tablished Agriculture Extension Department to provide technical assistance to the farming community, however, it is unknown whether they approach equally all farming communities to disseminate technical information among growers or not. The Department of Agriculture in AJ\&K is headed by a Director General. The directorates of agriculture extension and agriculture research were headed by a director. At the district level, the most senior official is the Deputy Director working under Director Extension Training and Adaptive Research (ETAR). Three circles (an administrative unit in the district comprising seven to 15 union councils) are covered by several Assistant Directors, working under the Deputy Director. Several Agriculture Officers (with graduate degrees in agriculture) are working under each Assistant Director each covering one circle. Several Field Assistants (with high school certification with science subjects plus a two-year diploma in agriculture) are working under each Agriculture Officer. One union council comprised of seven revenue villages is covered by each Field Assistant (FA). There are 230 total number of Field Assistants currently working in AJ\&K. The data regarding poverty is lacking in Azad Jammu \& Kashmir especially among the farming community, based on which the public sector decides to which extent efforts are needed for poor people to move them to a higher category of being non-poor. Hence, dire need was felt to measure the poverty status of apple growers along with interventions carried out by Agriculture Extension Department for problem solving and management of apple orchards for effective provision of extension services according to their category. Therefore, the most raising questions that need redress among policymakers and researchers are; whether there is a significant impact of agricultural technologies and extension services developed so far and whether poor farmers in AJ\&K can access agricultural extension services and adoption of agricultural technologies.

This study was designed to measure the poverty level of apple growers of extension users and non-extension users through a poverty scorecard and to find out the association between different extension services and poverty level in the study area in district Bagh of Azad Jammu and Kashmir.

\section{Materials and Methods}

using Sakran's (2003) table for the present study by using a multistage sampling technique. Azad Jammu and Kashmir constituted the universe of study. Out of ten districts, the study was conducted in district Bagh of AJ\&K. At the very first stage district, Bagh was selected purposively as apple orchards have been established in this area. After that two tehsils, Bagh and Dhirkot were also selected purposively as commercial apple fruit is produced in these areas. At the third stage out of total of 20 union councils, the data were collected randomly from six UCs. At the final stage, two villages from each union council were randomly selected. However, the data were analyzed at the tehsil level. Primary data were collected through a well structured interview schedule. The collected data were analyzed through Statistical Package for Social Sciences (SPSS) v.20. Data analysis was conducted by using percentages, frequency distribution, and twoway tabulation (cross tables). A poverty scorecard was also used to determine the poverty level of apple growers. Different categories were characterized on the basis of their cut-off points. The individuals in the category first of $0-11$ were considered extremely poor. The second category comprised of individuals who got a score of 12-18 range were considered as chronically poor. The third category was of transitory poor depicting score range of 19-23. The fourth category was transitory vulnerable having a score range of 2434. The last category for poor was transitory non-poor who gota score in the range of 35-50. All non-poor individuals were categorized in category six who fall in score range of 51-100. The cut-off points were according to the standards of World Bank score ranges. Poverty scorecard was filled through face-to-face interview and data collected were entered into the poverty scorecard to get the percentage of each category.

To investigate the relationship between different extension activities and poverty status of growers, Chi-square test was applied. Null hypothesis of the Chi-square test is that no relationship exists in the categorical variables in the population; they are independent.

The formula for Chi-square test is as under:

$$
\chi^{2}=\sum_{i=1}^{k} \frac{\left(O_{i}-E_{i}\right)^{2}}{E_{i}}
$$

A sample size of 306 respondents has been drawn by December 2021 | Volume 37 | Issue 4 | Page 1344 


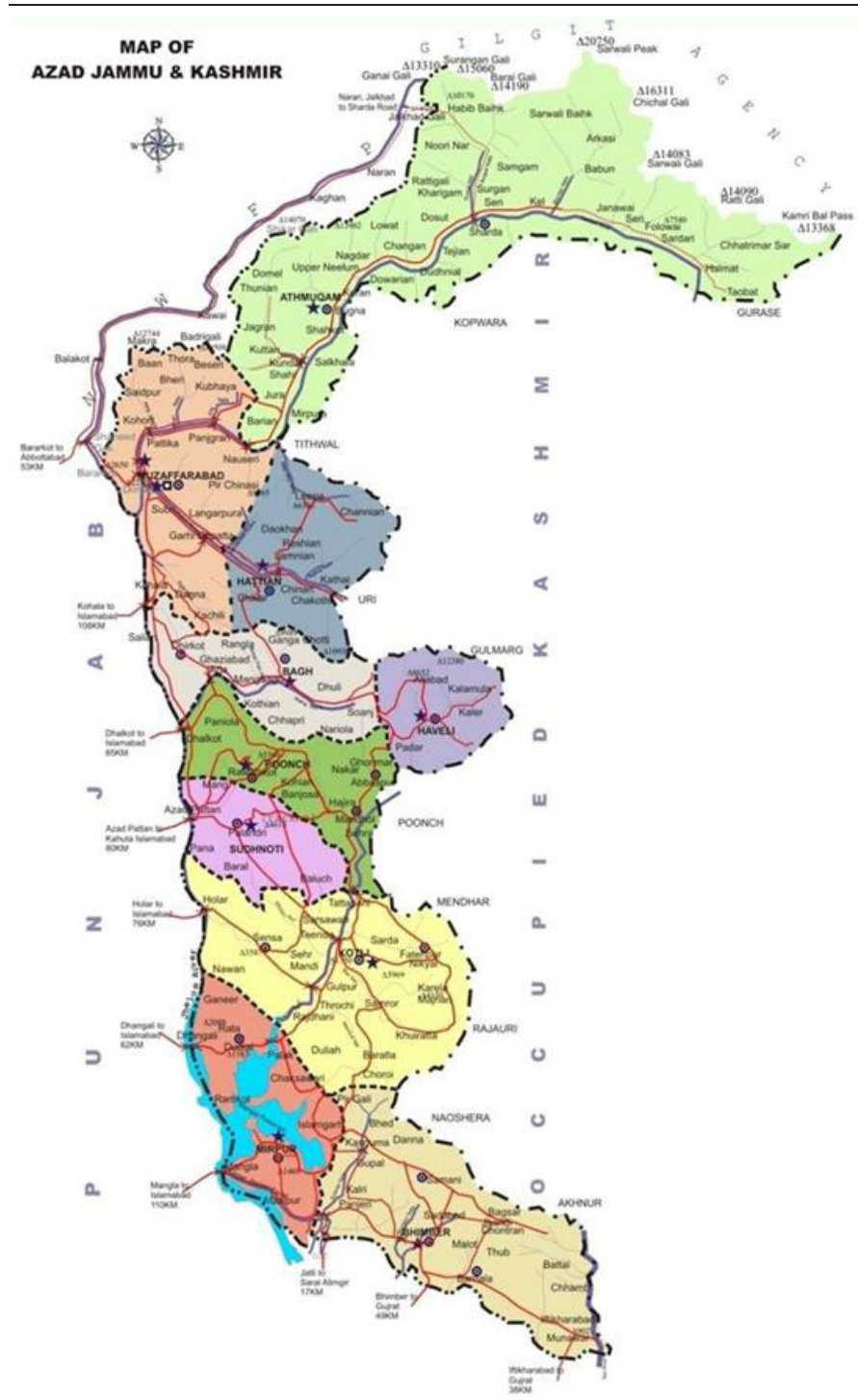

Figure 1: Map of $A J \xi K$.

\section{Results and Discussion}

Age

Farmer's age determines his ability to manage the orchard on the basis of their experience (Khair et al., 2006). Young growers are known to become less resistant to adopt any change as compared to old ones, as younger people rapidly adopt new technologies, and innovations which resulted in an accelerated rate of diffusion (Habib et al., 2007).

Age defines a person's reaction during different life practices. It has been agreed upon by many studies that age, creativity, and adaptability are strongly correlated. Table 2 shows that out of the total 306 respondents, majority $(45.4 \%)$ were in the middle age group of 36-60 years which depicts that middle age group apple growers are more active in orchard development. A higher level of acceptability regarding orchard management techniques was observed in this age group in the study area. The respondents in the age group of less than 35 years were $35.3 \%$ of the total sample size. The percentage of younger apple growers was observed less as compared to the middle age group because many young people have migrated to urban areas or overseas for employment and education. It was reported that the last age group of above 60 years was $19.3 \%$ of the total sample respondents. This infers that the productivity of apple orchard growers may reduce over time because majority of the elderly are not as energetic to perform activities related to orchard management as compared to the young and middle age growers. These results are in line with the research findings of Samuel (2000), who reported majority of the middle age farmers were involved in farming activities. Therefore, it becomes beneficial and essential to provide effective support services for increased productivity to this age group. The productive age bracket of extension agents reported by Ezeh (2013) was also between the age of 40 to 60 years.

Table 1: Poverty score-ranges matrix and cut-offs.

\begin{tabular}{|llll}
$\begin{array}{c}\text { Dependent } \\
\text { variable }\end{array}$ & $\begin{array}{l}\text { Cut off } \\
\text { Ranges }\end{array}$ & $\begin{array}{l}\text { Score } \\
\text { Ranges }\end{array}$ & Categories \\
\hline Poverty & 1 & $0-11$ & Extremely poor \\
& 2 & $12-18$ & Chronically poor \\
& 3 & $19-23$ & Transitory poor \\
& 4 & $24-34$ & Transitory vulnerable \\
& 5 & $35-50$ & Transitory non-poor \\
& 6 & $51-100$ & Non-poor \\
\hline
\end{tabular}

Table 2: Distribution of respondents on the basis of their age.

$\begin{array}{lllll}\text { Location } & \begin{array}{l}\text { Age (in years) } \\ \text { Less than 35 }\end{array} & \mathbf{3 6 - 6 0} & \mathbf{6 0} \text { above } & \text { Total } \\ \text { Dhirkot } & 72(23.5) & 89(29.1) & 38(12.4) & 199(65) \\ \text { Bagh } & 36(11.8) & 50(16.3) & 21(6.9) & 107(35) \\ \text { Total } & 108(35.3) & 139(45.4) & 59(19.3) & 306\end{array}$

Source: Field Survey

\section{Household size}

A group of people (could also be a single person) sharing common shelter, food items, and other living essentials is defined as a household (Bongaarts, 2001). Two or more individuals living in the same place and who share values, beliefs, and promises from longterm to each other is termed a household (Noonari et al., 2015). A study conducted in Nigeria showed that to determine poverty, household size matters, the household having a one person negatively and December 2021 | Volume 37 | Issue 4 | Page 1345 
significantly reduces poverty while there is a progressive increase in poverty by addition of members to the household members (Anyanwu, 2014). Usually, family members participate in agricultural activities hence; family size and farm are so much interlinked to each other and adds to the economic efficiency of any activity. However, it is also perceived that larger family size also contributes to poverty directly because of more dependency burden as compared to smaller household size. Thus, the controversy on the role of household size in poverty is still unanswered.

Table 3 demonstrates that out of the total sample respondents majority $(47.7 \%)$ had a household size of 5-8 persons. The minimum number of apple growers $(14.7 \%)$ falls in a group of household size of 1-4 persons. The sampled respondents in household size of $9-12$ were $22.5 \%$ and the apple growers above the household size of 12 persons were 15\%. This might infer that majority of the farmers are likely to experience a high dependency burden thereby affecting their savings and therefore raise low income. These results are aligned with the documented figure of the planning and development department AJ \& $\mathrm{K}$ where average size of the family 5-8 members were recorded at the national level.

Table 3: Distribution of sample respondents on the basis of their household size.

\begin{tabular}{llllll} 
Location & \multicolumn{2}{l}{ Household size } & \multicolumn{2}{r}{ Total } \\
& $\mathbf{1 - 4}$ & $\mathbf{5 - 8}$ & $\mathbf{9 - 1 2}$ & Above 12 & \\
Dhirkot & $33(10.8)$ & $\mathbf{7 4 ( 2 4 . 2 )}$ & $54(17.6)$ & $38(12.4)$ & 199 \\
Bagh & $12(3.9)$ & $\mathbf{7 2 ( 2 3 . 5 )}$ & $15(4.9)$ & $8(2.6)$ & 107 \\
Total & $45(14.7)$ & $146(47.7)$ & $69(22.5)$ & $46(15.0)$ & 306
\end{tabular}

Source: Field Survey

\section{Educational level of apple growers}

Generally, the educational system of Pakistan is divided into five levels viz; primary (grades 1 to 5); middle (grades 6 to 8); high (grades 9 and 10, leading to the Secondary School Certificate); intermediate (grades 11 and 12, leading to a Higher Secondary School Certificate); and Programs in Pakistani Universities lead to undergraduate and graduate degrees (Ozturk, 2001; Khan and Akram, 2012).

Educated farmers will be more efficient as they will adopt new agricultural technologies and their level of motivation will also be high (Khan et al., 2009). Education directly impacts reducing poverty by increasing income/earnings or wages. A positive correlation exists between communication and education in most economically developed and advanced countries. Hence, education and communication are strongly interlinked to each other (Khan and Akram, 2012).

Table 4: Distribution of sampled respondents on the basis of their educational level.

\begin{tabular}{lllllll|} 
Location & \multicolumn{2}{l}{ Educational Level } & & \multicolumn{2}{r|}{ Total } \\
& Illiterate & Primary & Middle & Matric & $\begin{array}{l}\text { Above } \\
\text { matric }\end{array}$ & \\
& & & & & & \\
Dhirkot & $50(16.3)$ & $62(20.3)$ & $51(16.6)$ & $19(6.2)$ & $17(5.6)$ & 199 \\
Bagh & $43(14.1)$ & $30(9.8)$ & $21(6.9)$ & $7(2.3)$ & $6(1.9)$ & 107 \\
Total & $93(30.4)$ & $92(30.1)$ & $72(23.5)$ & $26(8.5)$ & $23(7.5)$ & 306 \\
\hline
\end{tabular}

Source: Field Survey

Data presented in Table 4 show that 69.6 percent of the total sample respondents were literate while 30.4 percent were illiterate. The analyses of data further revealed that majority (30.1\%) of the sampled respondents were up to the primary level of education of the total literate sample. The fact behind this was that most villages were having educational schools up to the primary level. About $23.5 \%$ of sampled respondents have middle-level education followed by $8.5 \%$ with matric level of education while only $7.5 \%$ of sample respondents were above matric. As the literacy level of Azad Jammu and Kashmir is comparatively high as compared to other provinces of Pakistan hence, showing less number of uneducated farmers. Moreover, the fewer people having a higher level of education were mostly involved in government services hence not practicing apple orchard farming. It was also observed that adoption level in terms of management practices, application of scientific techniques like thinning, pruning is high in educated farmers as compared to uneducated farmers. It was noticed that illiterate people in the study area were reluctant to apply new technologies and rely on traditional methods hence may contribute to poverty. Mostly, it was noticed that the families having larger household size were contributing more to illiteracy in the study area as because of high dependency ratio household head could not afford to support the whole family to be educated. These results are more or less in consonance with the findings of Zafar et al. (2003) in which educational attainment confirmed that $25 \%$ of the respondents have been educated up to primary level, and this proportion fell by three percent and two percent as they moved from primary to the middle to matric level respectively. These results are also in line with the findings of Birdsall (2003) 
where farmers with four or more years of schooling in Thailand were three times more conceivable than less educated farmers to adopt fertilizer and other modern technologies.

\section{Farming experience}

Experience is very valuable for gaining advantages and reliability in any field of life (Khan and Akram, 2012). The number of years passed in the farming profession was regarded as farming experience. Farmer is considered as an institution within himself to gain knowledge with time through his experience. Hence, the common practice among the farming community is learning through experience.

Descriptive statistics in Table 5 revealed that majority of the sample respondents (42.2\%) had apple farming experience of about more than 20 years followed by $24.4 \%$ who possessed $16-20$ years of experience and $20.8 \%$ have $11-15$ years, whereas only $12.2 \%$ reported their experience with apple orchards up to 5-10 years. The least number of farming experiences were of those people who had recently adopted apple farming by getting inspiration from other successful growers. The most experienced growers were more efficient in techniques like pruning, spraying, picking, storing and marketing of apple fruit. The same results were reported by Ajayi and Gunn (2009) where the majority (84\%) of respondents had up to 30 years of farming experience.

Table 5: Distribution of sample respondents on the basis of their farming experience.

\begin{tabular}{llllll} 
Location & \multicolumn{2}{l}{ Farming Experience (years) } & \multicolumn{2}{r}{ Total } \\
& $\mathbf{5 - 1 0}$ & $\mathbf{1 1 - 1 5}$ & $\mathbf{1 6 - 2 0}$ & Above20 & \\
Dhirkot & $\mathbf{2 4}(7.9)$ & $\mathbf{4 8}(15.8)$ & $\mathbf{4 6}(15.2)$ & $\mathbf{7 9 ( 2 6 . 1 )}$ & 199 \\
Bagh & $\mathbf{1 3}(4.3)$ & $15(5.0)$ & $\mathbf{2 8}(9.2)$ & $50(16.5)$ & 107 \\
Total & $37(12.2)$ & $63(20.8)$ & $\mathbf{7 4}(24.4)$ & $129(42.6)$ & 306
\end{tabular}

Source: Field Survey

Poverty level of apple orchards growers

Table 6 depicted that out of the total sampled respondents, majority (60.1\%) of growers were in the category of non-poor. The overall situation in all villages elaborated that $10.5 \%$ of growers were in the category of transitory non-poor, $9.5 \%$ were in the stage of transitory vulnerable, $9.2 \%$ of growers were transitory poor. Only $5.9 \%$ of growers fall in the category of chronically poor. The least number of growers were in the category of extremely poor $(4.9 \%)$. There exist less variation in percentages of growers between extremely and chronically poor. The apple producers falling in poor categories explained that they were in this condition because of having no access to basic services even health, education and sanitation. They further elaborated that extension workers were not interested to change their status; instead, they usually focus on progressive apple producers. It was further assumed that ignorance contributes more towards poverty. These people were not well aware of even with the existence of a huge department of agricultural services. Moreover, there exists lack of policy reforms or special initiatives to provide diversified extension services for this marginalized group ultimately improving their socio-economic status. In addition, these growers shared that they usually applied traditional methods instead of modern intervention introduced by extension agents of their area.

\section{Association of extension services with poverty levels}

The bivariate analysis between the provision of extension services and poverty levels in Table 7 shows that $60.1 \%$ (184) apple growers were non-poor. Out of the non-poor category, $90.8 \%$ were provided with extension services. Hence, this shows a strong association between extension services and apple growers' poverty. Furthermore, only $9.2 \%$ in the non-poor category were those who were never provided with extension services. The next category of extremely poor comprises $4.9 \%$ of apple growers. All those who were extremely poor $(40.4 \%)$ were provided with extension services while $60.0 \%$ were those who were not provided with extension services. Furthermore, results showed that $5.9 \%$ of apple growers constituted the chronically poor category. For all those who were chronically poor $22.2 \%$ were accessed with extension services while $77.8 \%$ were never accessed with extension services. Hence depicting that the majority $77.8 \%$ of apple growers were those who were not facilitated with extension services. Similarly, $9.2 \%$ of apple growers were transitory poor, out of which $28.6 \%$ were provided with extension services and $71.4 \%$ were never facilitated with these services. Hence, if extension services were not provided to this group it would have been contributed to an increased number of apple growers in the transitory poor category. The transitory vulnerable category consists of $9.5 \%$ apple growers, out of which $58.6 \%$ were never provided extension services, while $41.4 \%$ were provided extension services. The last category of transitory 
Table 6: Distribution of respondents on basis of different poverty levels.

\begin{tabular}{llllllll} 
Location & Poverty level & \multicolumn{3}{c}{ Total } \\
& $\begin{array}{l}\text { Extremely } \\
\text { Poor }\end{array}$ & $\begin{array}{l}\text { Chronically } \\
\text { Poor }\end{array}$ & $\begin{array}{l}\text { Transitory } \\
\text { Poor }\end{array}$ & $\begin{array}{l}\text { Transitory } \\
\text { Vulnerable }\end{array}$ & $\begin{array}{l}\text { Transitory } \\
\text { Non-poor }\end{array}$ & Non-poor & \\
Dhirkot & $9(2.9)$ & $12(3.9)$ & $14(4.6)$ & $19(6.2)$ & $11(3.6)$ & $134(43.8)$ & 199 \\
Bagh & $6(2.0)$ & $6(2.0)$ & $14(4.6)$ & $10(3.3)$ & $21(6.9)$ & $50(16.3)$ & 107 \\
Total & $15(4.9)$ & $18(5.9)$ & $28(9.2)$ & $29(9.5)$ & $32(10.5)$ & $184(60.1)$ & 306
\end{tabular}

Source: Field Survey

Table 7: Association of extension services with poverty.

\begin{tabular}{lllllllll} 
Provision of extension services & \multicolumn{2}{l}{ Poverty levels } & & & \multicolumn{2}{c}{ Total } \\
& Non-poor & $\begin{array}{l}\text { Extremely } \\
\text { poor }\end{array}$ & $\begin{array}{l}\text { Chronically } \\
\text { poor }\end{array}$ & $\begin{array}{l}\text { Transitory } \\
\text { poor }\end{array}$ & $\begin{array}{l}\text { Transitory } \\
\text { vulnerable }\end{array}$ & $\begin{array}{l}\text { Transitory } \\
\text { non-poor }\end{array}$ \\
& No(\%) & No.(\%) & No.(\%) & No.(\%) & No.(\%) & No.(\%) & \\
Extension services Provided & $167(90.8)$ & $6(40.4)$ & $4(22.2)$ & $8(28.6)$ & $12(41.4)$ & $9(28.1)$ & $181(59.2)$ \\
Extension services never provided & $17(9.2)$ & $9(60.0)$ & $14(77.8)$ & $20(71.4)$ & $17(58.6)$ & $23(71.9)$ & $125(40.8)$ \\
Total & $184(60.1)$ & $15(4.9)$ & $18(5.9)$ & $28(9.2)$ & $29(9.5)$ & $32(10.5)$ & 306
\end{tabular}

$(d f=5, N=306) x^{2}=118.010, P-v a l u e=.000$, Kendall's tau $-c=-.564$

Table 8: Association of extension visits paid by extension staff with poverty.

\begin{tabular}{|c|c|c|c|c|c|c|c|}
\hline \multirow{3}{*}{ Ext. visits } & \multicolumn{6}{|c|}{ Poverty Levels } & \multirow[t]{3}{*}{ Total } \\
\hline & Non-poor & $\begin{array}{l}\text { Extremely } \\
\text { poor }\end{array}$ & $\begin{array}{l}\text { Chronically } \\
\text { poor }\end{array}$ & $\begin{array}{l}\text { Transitory } \\
\text { poor }\end{array}$ & $\begin{array}{l}\text { Transitory vul- } \\
\text { nerable }\end{array}$ & $\begin{array}{l}\text { Transitory } \\
\text { non-poor }\end{array}$ & \\
\hline & No (\%) & No $(\%)$ & No $(\%)$ & No $(\%)$ & No $(\%)$ & No $(\%)$ & \\
\hline Not paid & $17(9.2)$ & $9(60.0)$ & $14(77.8)$ & $20(71.4)$ & $17(58.6)$ & $23(71.9)$ & 100 \\
\hline Fortnightly & 19(10.3) & $0(0.0)$ & $1(5.6)$ & $1(3.6)$ & $1(3.4)$ & $0(0.0)$ & $22(7.2)$ \\
\hline Monthly & $40(21.7)$ & $2(13.3)$ & $1(5.6)$ & $3(10.7)$ & $1(3.4)$ & $1(3.1)$ & $48(15.7)$ \\
\hline Occasionally & $108(58.7)$ & $4(26.7)$ & 2(11.1) & $4(14.3)$ & $10(34.5)$ & $8(25.0)$ & $136(44.4)$ \\
\hline Total & $184(60.1)$ & $15(4.9)$ & $18(5.9)$ & $28(9.2)$ & $29(9.5)$ & $32(10.5)$ & 306 \\
\hline
\end{tabular}

$(d f=15, N=306) x^{2}=121.515, P$-value $=.000$, Kandalls tau-c=-.359

non-poor constituted $10.5 \%$ of apple growers, out of which $71.9 \%$ were never provided extension services while $28.1 \%$ were facilitated with these services. Hence, for those orchard growers who were not provided extension services their probability to fall in poor categories was in the range of 60 to 79 percent. Similarly, those orchard growers who were provided extension services, their probability to fall in poor categories was in the range of 41.4 to 22.2 percent. Moreover, the association between different poverty levels and extension services was found to be highly significant. This illustrates that by increasing the provision of extension services, the apple growers would move towards the higher category of non-poor.

Association of extension visits paid by extension staff with poverty of apple growers

Field visits provide an opportunity to learn practically through discussion and demonstrations with any extension agents in the local language learning by doing (Khan and Akram, 2012). Results of the bivariate analysis in Table 8 showed that 184 apple growers were in the non-poor category, 108 (58.7\%) were visited occasionally by extension agents. Almost $10.3 \%$ were visited fortnightly, $21.7 \%$ on monthly basis and $9.2 \%$ were never visited by extension agents. This shows a strong association of occasional visits with the non-poor status of apple growers. Hence, it is assumed that it's not the number of visits that matters but the quality of visits that matters. Moving towards categories of poor, $4.9 \%$ of apple growers were in the extremely poor category, out of which $13.3 \%$ were visited monthly and $26.7 \%$ occasionally and $60 \%$ were never visited by extension staff of the study area. Here the results reinforce the importance of visits paid by agricultural extension agents. The next 
category of chronically poor showed that for all those who fall in this group 77.8\% were never visited, 5.6\% each fortnightly and monthly visited, followed by $11.1 \%$ of occasional visits. Further, trends of poverty showed that for all those who were transitory poor, $71.4 \%$ were never visited, $10.7 \%$ were monthly and $14.3 \%$ were occasionally visited by extension agents. The transitory vulnerable category declared that for all those who constituted this group, $58.6 \%$ were never entertained by extension staff, followed by $34.5 \%$ who were visited occasionally. Moving towards the last category for all those who were transitory nonpoor, $71.9 \%$ were never visited by extension agents and $25 \%$ were occasionally visited. The overall higher percentage of growers constituting all categories of poor which were never visited by extension agents is alarming. This trend reflects that there are more chances of growers to fall in a chronically, transitory and transitory non-poor categories if not visited by extension agents. The advisory services i.e. visits of extension staff are provided free of charge to apple growers in the study area. The $\mathrm{P}$-value shows that there exists a statistically significant relationship between visits performed by extension agents and poverty levels. Moreover, the tau-c value directs the association between these variables. The negative sign demonstrates that by increasing extension visits poverty will reduce accordingly. Hence, there is a dire need to promote strong linkages between extension personnel and orchard growers through interactions. There exists a substantial difference between the yield of farmers those who were contacted by the extension workers as the main source of information as compared to others (Aker, 2011).

Association of different contact methods with poverty of apple growers

Extension can play its role in minimizing poverty through transfer of technologies and innovations to improve their livelihoods (Chikaire et al., 2011). Extension organizations intended to change the livelihoods of beneficiaries by adopting quality services procedures (Anderson and Feder, 2007). However, the credibility of extension field staff increases in eyes of farmers if methods are applied according to the prevailing situation of that area.

The bivariate analysis between different contact methods and poverty are presented in Table 9 which illustrates that for all those who were non-poor, 25\% were contacted by adopting farm/home visits, $27.2 \%$ through group meetings, only $9.8 \%$ were facilitated with demonstration method, $18.5 \%$ through telephone calls and $10.3 \%$ through other methods which mostly includes radio, print media, exhibitions and sometimes also through combinations of these methods. Thus, there exists a strong association between group meetings and farm/home visits with the poverty levels of apple growers. As non-poor category is comprised of more apple growers which were contacted through farm/home visits and group meetings. In farm/home visits each grower was addressed by examining fruit orchards at their places by clarifying the ambiguities. Growers feel comfortable because of face-to-face and personal interaction. Moreover, extension agent provides a deeper understanding of knowledge by reducing communication gap between them. In group meetings, apple growers gain more information from extension agents as well as from other apple growers based on their knowledge. Hence, these two methods were influencing poverty more, as compared to others. Furthermore, a total of $4.9 \%$ of apple growers constituting an extremely poor category, out of which 26.7\% were facilitated with demonstration method and $13.3 \%$ with telephone calls. Hence, there exists a relationship between the demonstration method and telephone calls with the extremely poor status of apple growers. As telephone/mobile is a quick way to avail specific information so growers also used this tool to facilitate themselves. Similarly, a total of $5.9 \%$ of apple growers constitutes the chronically poor category, out of which $11.1 \%$ were contacted through group meetings and $77.8 \%$ were never contacted. Here, group meetings showed association with the poverty of apple growers. This also infers the dominance of group meetings in the chronically poor category. Similarly, $9.2 \%$ of apple growers were in the transitory poor category, out of which $10.7 \%$ were contacted through group meetings, $7.1 \%$ through demonstration and $71.4 \%$ were never contacted through any extension method. Furthermore, for all those who were transitory vulnerable $20.7 \%$ were contacted through demonstration method. This category shows association of demonstration method with the poverty of apple growers. Moreover, $10.5 \%$ of apple growers were in the transitory non-poor category, out of which $71.9 \%$ were never contacted, however, $9.4 \%$ of apple growers were contacted through demonstration method and same for group meetings. However, in this category, $6.2 \%$ were approached through different other methods. Overall the variations among different percentages explain the association of each extension method with a specific group of apple growers 
Table 9: Association of different contact methods with poverty.

\begin{tabular}{llllllll} 
Contact method & \multicolumn{2}{l}{ Poverty level } & & & Total \\
& Non-poor & $\begin{array}{l}\text { Extremely } \\
\text { poor }\end{array}$ & $\begin{array}{l}\text { Chronically } \\
\text { poor }\end{array}$ & $\begin{array}{l}\text { Transitory } \\
\text { poor }\end{array}$ & $\begin{array}{l}\text { Transitory } \\
\text { vulnerable }\end{array}$ & $\begin{array}{l}\text { Transitory } \\
\text { non-poor }\end{array}$ \\
& No(\%) & No.(\%) & No.(\%) & No.(\%) & No.(\%) & No.(\%) & $23(71.9)$ \\
Never contacted & $17(9.2)$ & $9(60.0)$ & $14(77.8)$ & $20(71.4)$ & $17(58.6)$ & $100(32.7)$ \\
Home/farm visits & $46(25.0)$ & $0(0.0)$ & $1(5.6)$ & $1(3.6)$ & $2(6.9)$ & $1(3.1)$ & $51(16.7)$ \\
Group meetings & $50(27.2)$ & $0(0.0)$ & $2(11.1)$ & $3(10.7)$ & $2(6.9)$ & $3(9.4)$ & $60(19.6)$ \\
Demonstration & $18(9.8)$ & $4(26.7)$ & $1(5.6)$ & $2(7.1)$ & $6(20.7)$ & $3(9.4)$ & $34(11.1)$ \\
Telephone calls & $34(18.5)$ & $2(13.3)$ & $0(0.0)$ & $1(3.6)$ & $2(6.9)$ & $2(6.2)$ & $41(13.4)$ \\
others & $19(10.3)$ & $0(0.0)$ & $0(0.0)$ & $1(3.6)$ & $0(0.0)$ & $0(0.0)$ & $20(6.5)$ \\
Total & $184(60.1)$ & $15(4.9)$ & $18(5.9)$ & $28(9.2)$ & $29(9.5)$ & $32(10.5)$
\end{tabular}

$(d f=25, N=306) x^{2}=140.822, P$-value $=.000$, Kendall's tau-c=-.323

Table 10: Association of poverty with extension strategies.

\begin{tabular}{|c|c|c|c|c|c|c|c|}
\hline \multirow{3}{*}{$\begin{array}{l}\text { Extension strat- } \\
\text { egies }\end{array}$} & \multicolumn{6}{|c|}{ Poverty level } & \multirow[t]{3}{*}{ Total } \\
\hline & Non-poor & $\begin{array}{l}\text { Extremely } \\
\text { poor }\end{array}$ & $\begin{array}{l}\text { Chronically } \\
\text { poor }\end{array}$ & $\begin{array}{l}\text { Transitory } \\
\text { poor }\end{array}$ & $\begin{array}{l}\text { Transitory } \\
\text { vulnerable }\end{array}$ & $\begin{array}{l}\text { Transitory } \\
\text { non-poor }\end{array}$ & \\
\hline & No (\%) & No. (\%) & No. $(\%)$ & No. (\%) & No. (\%) & No. (\%) & \\
\hline No strategy & $17(9.2)$ & $9(60.0)$ & $14(77.8)$ & $20(71.4)$ & $17(58.6)$ & 23(71.9) & $100(32.7)$ \\
\hline $\begin{array}{l}\text { Community } \\
\text { empowerment }\end{array}$ & $91(49.5)$ & 2(13.3) & $1(5.6)$ & $6(21.4)$ & $8(27.6)$ & $7(21.9)$ & $51(16.7)$ \\
\hline Linkages & $54(29.3)$ & $2(13.3)$ & $1(5.6)$ & $2(7.1)$ & $4(13.8)$ & $2(6.2)$ & $60(19.6)$ \\
\hline Diversification & $22(12.0)$ & $2(13.3)$ & $2(11.1)$ & $0(0.0)$ & $0(0.0)$ & $0(0.0)$ & $34(11.1)$ \\
\hline Total & $184(60.1)$ & $15(4.9)$ & $18(5.9)$ & $28(9.2)$ & $29(9.5)$ & $32(10.5)$ & $41(13.4)$ \\
\hline
\end{tabular}

$(d f=15, N=306) x^{2}=124.117 P-v a l u e=.000$ tau $-c$ value $=-.394$

concerning poverty. Moreover, the data depicts which extension method is suitable for which group to move apple growers from the lower category of being poor to the higher category of being non-poor. Overall, from the $\mathrm{p}$-value it is evident that there exists a highly significant relationship between different contact methods and poverty of the apple growers. Change in this behavior of the farmers is the prime agenda of extension workers with the help of a prudent combination of different methods, but it is necessary that all learning should carry out according to the current resources of any community.

Association of extension strategies with poverty of apple growers

The process of community empowerment in terms of extension demands for sustainable development of all socio-economic components (Asiabaka, 2003). Bivariate analysis in Table 10 depicted that $60.1 \%$ (184) apple growers were non-poor, out of which $49.5 \%$ were empowered through community empowerment strategy, 29.3\% were trained to develop linkages with other sectors, $12.0 \%$ were supported through diversification. Here community empowerment and linkages showed more strong relationship with the poverty of apple orchards as compared to diversification. Community empowerment is dominating in the study area as this strategy enables orchards growers to help themselves to utilize improved practices related to apple farming for income enhancement. The extension agents usually deal to educate growers' organizations about their rights from production to distribution of apple products in markets. Furthermore, extension agents tend to bind orchards growers in the form of community organizations despite having so many socio-economic differences among themselves. This is the reason that's why community empowerment contributes a lot to the poverty reduction of apple orchard growers. Similarly, the second strategy linkages foster the association of farmers with research and other institutes to access services offered by them. Hence, it is concluded that by promoting strong linkages between farmers and other service providers, poverty will reduce effectively. The third strategy diversification 
Table 11: Association of poverty with training provided.

\begin{tabular}{|c|c|c|c|c|c|c|c|}
\hline \multirow[t]{3}{*}{ Training } & \multicolumn{6}{|c|}{ Poverty levels } & \multirow[t]{3}{*}{ Total } \\
\hline & Non-poor & $\begin{array}{l}\text { Extremely } \\
\text { poor }\end{array}$ & $\begin{array}{l}\text { Chronically } \\
\text { poor }\end{array}$ & $\begin{array}{l}\text { Transitory } \\
\text { poor }\end{array}$ & $\begin{array}{l}\text { Transitory } \\
\text { vulnerable }\end{array}$ & $\begin{array}{l}\text { Transitory } \\
\text { non-poor }\end{array}$ & \\
\hline & No $(\%)$ & No. $(\%)$ & No. $(\%)$ & No. $(\%)$ & No. $(\%)$ & No. $(\%)$ & \\
\hline Trainings attended & $123(66.8)$ & $8(53.3)$ & $8(44.4)$ & $12(42.9)$ & $17(58.6)$ & $13(40.6)$ & $181(59.2)$ \\
\hline Trainings not attended & $61(33.2)$ & $7(46.7)$ & $10(55.6)$ & $16(57.1)$ & $12(41.4)$ & $19(59.4)$ & $125(40.8)$ \\
\hline Total & $184(60.1)$ & $15(4.9)$ & $18(5.9)$ & $28(9.2)$ & $29(9.5)$ & $32(10.5)$ & 306 \\
\hline
\end{tabular}

$(d f=5, N=306) x^{2}=13.958, P$-value $=.001$, Kandalls tau-c=-.190

is associated with poverty reduction because diversification has brought about a greater integration and interdependency between farm households and rural economies. By applying this strategy farm characteristics that relates to farming systems and production technology were analyzed by extension staff to diversify services. According to Knickel and Renting (2000), the relations between farm-household diversification and rural economies are central in the process of multi-functionality and the provision of public goods through agricultural activities. Vogel (2012) estimates that the contribution of on-farm diversification activities to the total value of US agricultural production is about 40\%. Carter (1999) have reported positive effects of diversification activities on rural development. The results also showed that $4.9 \%$ of apple growers were in the extremely poor category, out of which, $60 \%$ were never facilitated with any extension strategy, while $13.3 \%$ were facilitated with community empowerment and an equal number of farmers through linkages and diversification strategies. The equal number of growers for each extension strategy shows that all three strategies are associated in equal terms with poverty. Therefore, results showed that all three strategies were equally applied for this group by extension agents. Hence, not only one strategy can be regarded best for more poverty reduction among growers of this miserable group. However, among all those who fall in the chronically poor category, $11.1 \%$ were mobilized through the strategy of diversification. Hence, diversification is associated with poverty more as compared to other strategies for extremely poor apple growers. For all those who fall in the transitory poor category, $21.4 \%$ were empowered through community empowerment and $7.1 \%$ through diversification. Hence, this group of poor apple growers is influenced by community empowerment. Furthermore, for all those who fall in the transitory vulnerable, $27.6 \%$ were empowered through community empowerment and only $13.8 \%$ through developing linkages with other departments for their welfare. Therefore, com- munity empowerment is associated with the poverty of apple growers in this category. Moreover, for all those who fall in the transitory of non-poor category, $21.9 \%$ of them were stimulated through community empowerment. The overall $\mathrm{p}$-value shows that there exists a significant association between different extension strategies and poverty.

\section{Association of trainings with poverty}

The main capacity building method in developing countries is through training. However, it is recommended that government, organizations intervention agencies and private extension organizations should provide adequate funds for trainings. Moreover, existing training centers should be upgraded according to the needs of farmers, which may include audio-visual aids to reinforce the extension teachings (Kumari and Khanduri, 2019).

The bivariate analysis given in Table 11 shows poverty trends of each group with those who attended training sessions conducted by extension agents and those who did not attend these training sessions. The data inferred that all those who were non-poor, $66.8 \%$ were those who attended the trainings and 33.2\% who did not attend any training. Hence, the results showed that the non-poor category constituted more apple growers who attended the training. Here, the results also declared that there exists an association of training with the poverty of apple growers. Training content is mostly based on skills development activities to encourage farmers to use technologies more appropriately. These trigger growers to enhance their income opportunities to reduce poverty. Similarly, $4.9 \%$ of apple growers were extremely poor, out of which, 53.3\% attended training and $46.7 \%$ did not attend any training. Thus, there exists an association between training and poverty of apple growers. Moreover, $5.9 \%$ of apple growers were chronically poor, out of which $44.4 \%$ attended trainings and $55.6 \%$ did not attend any training session. Extension December 2021 | Volume 37 | Issue 4 | Page 1351 
workers should focus on this poor category of apple growers to improve their socio-economic status by engaging them in more training programs. Moreover, of all those who were transitory poor, $42.9 \%$ attended trainings and $57.1 \%$ never attended. Furthermore, of all those who were transitory vulnerable, $58.6 \%$ attended trainings and $41.4 \%$ never attended. The last category of transitory non-poor showed that $40.6 \%$ attended training sessions given by extension department and $59.4 \%$ did not attend any training session. Every poor group should identify their problems based on need assessment hence contributing to poverty reduction.

By improving strategies, training contents, farmers' participation, delivering and evaluating training programs, more and more farmers will pull out from lower poverty levels towards the higher category of being non-poor. Hence, follow-up support should be provided for extension staff of the study area. There exists a statistically significant association between trainings and poverty levels. Therefore, it is concluded that poverty will reduce by engaging growers in trainings for capacity building.

\section{Conclusions and Recommendations}

Based on the results of the study it is found that majority of the apple growers were educated and middle-aged hence, concluded that more educated and energetic farmers were involved in this activity in the study area. Furthermore, overall the role of the extension agent was also perceived as positive by the growers who had taken care of apple orchards by implementing suggestions of extension agents. Regarding trainings higher level of income was observed as compared to those growers who have not accessed or attended training sessions from the extension staff. Majority of the sample respondents had apple farming experience of more than 20 years, whereas only some of the respondents reported their apple farming experience of 5-10 years, which concludes that apple farming was dominated by experienced people \& being profitable activity it was being practiced since many years back.

It was also concluded that extension services, visits were paid by extension workers, different contact methods, extension strategies and trainings were significantly associated with poverty level. Hence, by increasingthe provision of extension services through different contact methods apple growers would move towards a higher category of non-poor. Moreover, it is observed that majority of non-poor were those respondents who were provided with extension services, depicting the positive role of extension services in poverty reduction. By providing trainings of capacity building, poverty will also be reduced. Mostly farm/ home visits were used for the dissemination of information to different categories of the poor growers. It was concluded as well that most apple growers were occasionally visited by the extension personnel which indicates mobility issues in the area.

Based on the findings of the research study, the following recommendations were formulated for apple growers/policy makers in the study area:

1. The educated and experienced farmers were involved in fruit orchard management in Azad Jammu \& Kashmir, hence their attitude towards adaptability of any innovative technology is encouraging, and therefore, farmers should be equipped with the latest technical information and innovative techniques to enhance the productivity of apple fruit crop.

2. It was quite evident from the results that many growers were not provided with agriculture extension services, hence government policy needs to exploit the reasons why a particular group is marginalized. The percentage of farmers in the poor category was more who were not visited and agriculture extension agents mostly visited occasionally to rest of the growers. Visits should be regularized by providing transportation facilities or traveling allowances for the smooth working of extension workers.

3. Results reinforce the importance of group meetings and farm/home visits but it was observed that information communication technologies are underutilized hence awareness regarding usage of ICT tools should be encouraged as of mobile phones to communicate with famers in far-flung mountainous areas of Azad Jammu \& Kashmir.

4. To boost the effectiveness of extension services, efforts need to be directed to focus on the most effective extension strategies by increasing the participation of growers in community empowerment programs. Moreover, there is a need to build strong linkages with other stakeholders along with diversification in extension activities for poverty reduction.

5. Policies regarding poverty reduction to move ap- 
ple growers froma lower to a higher poverty level of being non-poor be formulated to meet challenges by delivering extension services.

\section{Novelty Statement}

The novelty of this research is the effective regularization/implementation of agricultural extension services for reduction of poverty for apple growers in District Bagh, Azad Jammu and Kashmir.

\section{Authors Contribution}

Sana Javeid: Principal author/PhD scholar, who conducted research, data collection and analysis.

Khalid Nawab: Major Supervisor, who provided technical guidelines in the whole research study.

\section{References}

Ahmed, M.J. and M. Raza. 2005. Effect of pruning and fertilizer application on growth, yield and quality of apple (Malusdomestica). Sarhad J. Agric., 21(2): 193-196.

Ajayi, O.J. and E.E. Gunn. 2009. The role of communication in dissemination of improved agricultural technology in Bosso local government area of Niger, Nigeria. J. Agric. Ext., 13(1): 6672. https://doi.org/10.4314/jae.v13i1.53879

Aker, J. C. 2011. Dial "A" for agriculture: a review of information and communication technologies for agricultural extension in developing countries. J. Agric. Econ., 42(6): 631-647. https:// doi.org/10.1111/j.1574-0862.2011.00545.x

Amalu, U.C. 2005. Poverty alleviation and agriculture in sub-Saharan Africa, the Nigeria Experience, J. Food Agric. Environ., 3(2): 230-236.

Anderson, J.R. and G. Feder. 2007. Rural extension services: Agriculture and rural development department World Bank, Washington DC. World Bank policy research working paper. 2976. Pp: 20-23.

Anyanwu, J.C. 2014. Marital status, household size and poverty in Nigeria: Evidence from the 2009/2010 survey data. Afr. Dev. Rev., 26(1): 118 - 137. https://doi.org/10.1111/14678268.12069

Asante, F. and R.A. Ayee. 2004. Decentralization and poverty reduction. In Ernest Aryetey and Ravi Kanbur . The economy of Ghana: Analytical perspectives on stability, growth and poverty.
Retrieved from www.saga.cornell.edu

Asiabaka, C. 2003. Promoting sustainable practice to best fit: A framework for analyzing extension approaches: Farmer field school (FFS) agricultural advisory services worldwide and its role in sustainable agricultural development. Development strategy and governance division, Retrieved from http://www.codesria.org/IMG/ pdf/

Azad Jammu and Kashmir Statistical Year Book. 2018. https://www.pndajk.gov.pk/upload files/ downloads/statistic.pdf

Bigsten, A., B. Kebede, A. Shimeles and M. Taddess. 2003. Growth and Poverty Reduction in Ethiopia guidance from household panel surveys. World Dev., 31(1): 87-106. https://doi. org/10.1016/S0305-750X(02)00175-4

Birdsall, N. 2003. Social development in economic development. World bank policy research working papers, WPS 1123, Washington DC. pp. 14-18.

Bongaarts, J. 2001. Household size and composition in developing world in 1990's: Population studies. A J. Demogr., 55(3): 263-279. https:// doi.org/10.1080/00324720127697

Birner, R., and K.R. Anderson. 2007. How to make agricultural extension demand driven? IFPRI Discussion paper 00729.

Carter, S. 1999. Multiple business ownership in the farm sector: Assessing the enterprise and employment contributions of farmers in Cambridgeshire. J. Rural Stud., 15: 417-429. https:// doi.org/10.1016/S0743-0167(99)00004-2

Chikaire, J., F. Nnadi, N. Nwakwas and N. Ejiogu. 2011. The changing roles of agricultural extension to achieve food security and improve rural livelihoods in Imo State, Nigeria. Department of Agricultural Extension. Federal university of Technology Owerri. Department of Agricultural Management and Extension.

Dercon, 2008. Risk, poverty, and human development: what do we know, what do we need to know? background paper to the human development report.

Dewbre, J., D.C. Godoy and S. Sorescu. 2011. Agricultural progress and poverty reduction: synthesis report, OECD Food, Agriculture and fisheries working paper. No. 49. OECD Publishing. Pp. 67-69.

Ezeh, A.N. 2013. Extension agents access and utilization of information and communication 
technology (ICT) in extension service delivery in South East Nigeria. J. Agric. Ext. Rural Dev., 5(11): 266-276.

FAO. 2000. FAOSTAT Database. http://apps.fao. org

Habib, M., M.Z. Khan, M. Iqbal, K. Nawab and S. Ali. 2007. Role of farmer field school on sugarcane productivity in Malakand Pakistan. Afr. Crop Sci. Conference Proceedings. Pp. 1443-1446.

IFAD. 2016. Investing in rural people in Pakistan. International fund for agricultural development (IFAD), Rome Italy.

Khair, S.M., M.N. Shahwani and S.A. Sattar. 2006. Production constraints of apple in Balochistan. J. Appl. and Emerg. Sci. 1(3): 167-173.

Khan, A. and M. Akram. 2012. Farmers' perception of extension methods used by extension personnel for dissemination of new agricultural technologies in Khyber Pakhtunkhwa, Pakistan. Sarhad J. Agric. 28(3): 511-520.

Khan, A., U. Pervaiz, N. Khan, M. Ahmad and S. Nigar. 2009. Effectiveness of demonstration plots as extension method adopted by AKRSP for agricultural technology dissemination in district Chitral. Sarhad J. Agric. 25(2):313-319.

Knickel, K. and H. Renting.2000. Methodological and Conceptual Issues in the Study of Multifunctionality and Rural Development. Sociologia Ruralis. 40: 512-528. https://doi. org/10.1111/1467-9523.00164

Kumari, S. and V. Khanduri. 2019. Capacity development for farmers and their service providers.

Minten, B. and B. Barrett. 2006. Agricultural technology, Productivity, Poverty and Food security in Madagascar. SAGA Working Paper. https://doi.org/10.2139/ssrn.716142

Noonari, S., I.N.Memon, R. Wahid, M.B. Peerzada and M.A. Bhatt. 2015. Economic analysis of apple orchards production in District Mastung Balochistan Pakistan. Econ. Anal. 7(10): 271280.

Ozturk, I. 2001. The role of education economic development: A theoretical perspective. J. Rural Dev. Adm. 23(1): 39-47.

Ritter, M. 2006. The physical environment. An Introduction to Physical Geography. http:// www.uwsp.edu/geo/faculty/ritter/geog101/ textbook/title_page.html Accessed on 22.07.2020.

Sachs, D.J. 2006. Millennium Project, UK. pp. 9598.

Sakaran, U. 2003. Research methods for business: USA. Harnitage Publishing services. Pp. 468.

Samuel, G. 2000. A study on the impact of integrated rural development programme (IRDP) in Medak district of Andhra Pradesh. Ph.D. dissertation, Acharya N.G. Ranga Agric. Univ., Hyderabad. Pp. 67-69.

Siddique, N.B., S. Muhammad and N.H. Malik. 2006. Effect of socio-economic aspects on the awareness and adoption of recommended horticultural practices by apple growers in Balochistan, Pakistan. Pak. J. Agric. Sci., 43(1): 127-134.

United Nations. 2015. Transforming our world: the 2030 Agenda for Sustainable Development. New York: United Nations.

Vogel, S. 2012. Multi-enterprising Farm Household: The Importance of their alternative business ventures in the rural economy. EIB-101, US Department of Agriculture, Econ. Res. Serv. October 2012. Washington, DC. https:// doi.org/10.2139/ssrn.2171368

World Bank. 2007. Agriculture for Development. World Bank/Oxford University Press, Washington, DC/ Oxford. Agriculture and development: A brief review of the literature. Pp. 121128.

World Bank. 2007b. World development Report. Agriculture for development. Washington, D.C. World Bank.

World Bank.2008. World development report. Agriculture for development, New York: Oxford University Press. pp.28-34.

Zafar, I.M., S.U. Rehman, S. Akbar, W. Malik and K. Ahmed.2003. Natural resource management through community-based approach in Kotli, AJK. The role of National Rural Support Programme. Pak. J. Agric. Sci. 40(1): 59-68.

Zivkovic, D., S. Jelic and Z. Rajic. 2009. Agricultural extension services in the function of rural development. Seminar on 'The role of knowledge, innovation and human capital in multifunctional agriculture and territorial rural development. Belgrade, Republic of Serbia. Pp. 517-525. 